Katarzyna Błaszczuk

(Uniwersytet Rzeszowski)

\title{
Kształtowanie postaw dzieci i młodzieży wobec zdrowia jako wartości Rozwój Sieci Szkół Promujących Zdrowie w województwie podkarpackim
}

\section{Wstęp}

Postawy wobec zdrowia zależą od stylu życia i kultury, w której człowiek jest wychowany. Decydujace znaczenie w zdobywaniu doświadczeń z zakresu ochrony zdrowia i postępowania $\mathrm{w}$ przypadku jego zagrożenia ma środowisko rodzinne, dlatego trudno jest człowiekowi zmienić utrwalone nawyki wyniesione $\mathrm{z}$ domu. Jest truizmem twierdzenie, że jakość powietrza atmosferycznego, wody służącej do picia i zaspokajania potrzeb higienicznych, do uprawy roślin i hodowli zwierząt gospodarskich oraz jakość spożywanej żywności to warunki niezbędne do utrzymania zdrowia siedliskowego i ochrony przed czynnikami ryzyka. Jednak pomimo posiadanej w tym zakresie wiedzy, ludzie coraz częściej sięgaja po produkty spożywcze wysoko przetworzone i konserwowane, zanieczyszczaja środowisko przez spalanie odpadów przeznaczonych do utylizacji, stosowanie pestycydów, nawozów sztucznych i detergentów.

Do czynników warunkujących potencjał zdrowotny w sferze psychicznej i społecznej zaliczamy umiejętność radzenia sobie ze stresem sytuacyjnym, poprawne relacje intra/interpersonalne oraz niezaburzoną komunikację społeczna. Konflikty, długotrwały stres i brak poczucia satysfakcji życiowej również wpływają niekorzystnie na zdrowie somatyczne. Kolejnymi zagrożeniami są: bezrobocie, kryzys ekonomiczny i coraz większa przepaść pomiędzy osobami/grupami posiadającymi wysoki standard życia, a żyjącymi na poziomie niegwarantującym minimum socjalnego czy egzystencjalnego. Ponadto prezentowane w przestrzeni wirtualnej modele życia i konsumpcji obce naszej kulturze 
nasilają tendencje do podążania za tymi standardami, często bezkrytycznie, w szybkim tempie. Niejednokrotnie człowiek odczuwa rozczarowanie, gdy zamiast spodziewanych korzyści ponosi wysokie koszty materialne i naraża się na utratę zdrowia.

Opracowanie jest próbą ukazania zmian postaw wobec zdrowia na podstawie literatury przedmiotu i realizacji celów wytyczonych przez Światową Organizację Zdrowia (WHO) w programie Szkół Promujących Zdrowie (SzPZ), opartym na priorytetach określonych przez Narodowy Program Zdrowia (NPZ).

\section{Koncepcje zdrowia w ujęciu historycznym}

Hipokrates nazywany „ojcem medycyny europejskiej” twierdził, że równowaga między człowiekiem i jego otoczeniem zapewnia zdrowie, a brak tej równowagi oznacza chorobę. Była to historyczno-ewolucyjna koncepcja zdrowia. Z kolei Kartezjusz porównywał organizm ludzki do precyzyjnej i doskonale działającej maszyny. Tę koncepcje nazwano mechanistyczno-redukcjonistyczna, ponieważ panowało przekonanie, że w przypadku choroby należy „naprawiać” zdrowie człowieka chorego jako „uszkodzonej maszyny biologicznej” (Kulik 2002: 16).

W starożytności uważano, że niezależnie od wieku, ruch i racjonalne żywienie mają duże znaczenie w życiu człowieka. Galen uznał, że ciało ludzkie składa się z czterech płynów (krew, flegma, żółć żółta, żółć czarna), którym odpowiadają cztery elementy tworzące świat (powietrze, woda, ogień ziemia) i jego jakości (goraco, wilgotno, sucho, zimno), a zdrowie zależy od zrównoważonego i proporcjonalnego zmieszania płynów ustrojowych. Uznawał także dwa źródła zagrożenia zdrowia człowieka: wewnętrzne - podeszły wiek oraz zmiany w stałym obiegu substancji w organizmie, i zewnętrzne - czynniki środowiska (Karczewski 2002: 6).

Lekarze greccy i rzymscy opierali pojęcie zdrowia na zachowaniu równowagi następujących czynników: powietrza i światła, jedzenia i picia, ruchu i odpoczynku, snu i czuwania, wydzielania i wydalania oraz emocji. Wyróżniono zależne i niezależne od człowieka czynności fizjologiczne oraz odchylenia patologiczne. Według Platona zdrowie oznaczało doskonalenie stylu życia zwiazanego z dieta oraz rozwojem duchowym i kulturalnym. Plutarch zalecał aktywność i pracę. Stoicy przypisywali zdrowiu fizycznemu niska wartość, uznając za najważniejsze dla zdrowia rozwój i harmonię umysłową. Miernikiem poziomu kultury w czasach starożytnych był sposób życia w zdrowiu i radzenie sobie w chorobie. 
Piękno i cnota stanowiły jedność, a gimnastyka, muzyka, taniec i poezja miały służyć ciału i duszy. Najważniejsza w postępowaniu terapeutycznym była dieta, następnie farmakoterapia, a na końcu chirurgia (Karczewski 2002: 7).

W chrześcijańskim średniowieczu zdrowie oznaczało nie tylko brak choroby i cierpienia, ale także zdolność do ich znoszenia. Uważano, że choroba to boska kara za grzechy. Ciało traktowano jako „naczynie duszy”, które należało utrzymywać w czystości. Porządek klasztorny wprowadzał zasady higieny ogólnej i higieny żywienia. Paracelsus został uznany za symbol przejścia od średniowiecza do czasów nowożytnych, jako twórca doktryny makro- i mikrokosmosu. Według niej zdrowie nie jest dawane przez nature, tylko musi być ciagle zdobywane, a czas śmierci zależy wyłącznie od człowieka (Karczewski 2002: 8).

Coraz większe skupiska ludności związane z rozwojem miast miały wpływ na wzrost ryzyka chorób. Zaniedbania higieniczne, brak dostępu do dobrej jakościowo wody, brak kanalizacji, transport i magazynowanie żywności - skutkowały występowaniem wielu chorób zakaźnych i epidemii dziesiatkujacych ludność Europy. Wobec sytuacji zagrożenia zdrowia całych populacji opracowano normy postępowania $\mathrm{w}$ formie przepisów o porządkach sanitarnych, o kontroli handlu żywnością, o postępowaniu na wypadek epidemii. Dla poprawienia stanu higieny publicznej budowano urządzenia sanitarne (wodociagi, kanalizację, łaźnie publiczne). Nad przestrzeganiem przepisów czuwała policja sanitarna (Karczewski 2002: 8).

Około połowy XIX wieku wyodrębniono publiczna służbę zdrowia pod kierunkiem lekarzy-higienistów oraz stworzono fundamenty pod higienę naukowa. Anglia była pierwszym krajem, w którym powołano instytucje sprawujace nadzór nad zdrowiem ludności i higiena komunalną. Warunki życia proletariatu przemysłowego uragały zasadom higieny, co sprzyjało epidemiom, zaś ruch handlowy łączący porty angielskie z krajami kolonialnymi powodował inwazję chorób tropikalnych. Angielski model publicznej służby zdrowia i higieny komunalnej stał się wzorem dla Europy i Ameryki Północnej. Odkrycia Pasteura, Kocha i Pettenkoffera przyczyniły się do rozwoju mikrobiologii, epidemiologii i higieny. Pettenkoffer założył pierwsza na świecie Katedrę Higieny na Wydziale Lekarskim Uniwersytetu w Monachium w 1864 r. Uznano go za prekursora higieny jako samodzielnej dyscypliny naukowej. Na jego cześć nazwano normę zanieczyszczenia powietrza $0,1 \% \mathrm{CO}_{2}$ wskaźnikiem Pettenkoffera (Karczewski 2002: 9).

Przed 1918 r. działali w Polsce wybitni uczeni w dziedzinie higieny: profesor Teofil Wisłocki, profesor Odo Bujwid, Józef Polak. Po odzyskaniu niepodległości ówczesne władze państwowe powołały Państwowy 
Zakład Higieny. Wybitnymi higienistami w Polsce międzywojennej byli profesorowie: Witold Chodźko w Lublinie i Marcin Kacprzak w Warszawie. Higiena to dziedzina naukowa, która miała ogromne znaczenie w określaniu norm czynników potęgujących zdrowie i eliminowaniu przyczyn zagrożeń zdrowotnych (Karczewski 2002: 9).

\section{Współczesne koncepcje zdrowia}

Przemiany środowiska fizycznego i społecznego mają wpływ na sfere zdrowia jednostki i społeczeństwa. Wzrasta liczba czynników, które „wymuszają" na organizmie człowieka konieczność dokonywania rozmaitych „metamorfoz” niezbędnych do przystosowania się do życia i funkcjonowania w środowisku oraz możliwości obrony przed zagrożeniami. Dotyczy to zarówno warunków środowiska, jak też nowych obcych dla organizmu substancji. Im więcej „nowości” wprowadzamy bezpośrednio do organizmu lub do środowiska, tym trudniej zapobiegać niekorzystnym wpływom na zdrowie, czego przykładem może być wzrost liczby zachorowań na alergie i nowotwory.

Jednym z następstw procesu transformacji systemowej i globalizacji jest zjawisko wzmożonych migracji, które dotyczy głównie ludności z regionów o niskim standardzie życia, wysokiej stopie bezrobocia i pogłębiajacym się kryzysie ekonomicznym. Sytuacje pogarsza fakt starzenia się społeczeństwa, brak zabezpieczeń socjalnych sprzyjających odnawialności pokoleń (brak mieszkań, błędna polityka prorodzinna, priorytet kariery zawodowej i poziomu konsumpcji nad wartościami gwarantujacymi stabilna sytuacje rodziny oraz wychowanie potomstwa $\mathrm{w}$ poczuciu bezpieczeństwa). Jedyna droga do utrzymania i poprawy potencjału zdrowotnego jest wzrost odpowiedzialności człowieka za skutki ingerencji w środowisko, poprzez zastosowanie środków prewencyjnych, zapobiegajacych działaniom wbrew naturze.

Pierwsza definicja zdrowia, przyjetta przez WHO w 1948 r., brzmiała: „Zdrowie to pełen dobrostan fizyczny, psychiczny i społeczny, a nie wyłącznie brak choroby bądź niedomagania” (Karczewski 2002: 11). $\mathrm{W}$ latach 60 . XX w. uznawano wpływ uwarunkowań genetycznych za istotny czynnik dla zdrowia międzypokoleniowego, co określała definicja: „Zdrowie to stan lub zdolność organizmu ludzkiego do wykazywania odpowiednich czynności w określonych warunkach środowiskowych i genetycznych" (Karczewski 2002: 12). Definicja zdrowia z lat 90. XX w., nazywana „ekologiczno-ewolucyjna” głosi: „Zdrowie jest to stan swoistej równowagi albo oddziaływania między układem, jaki stanowi organizm 
człowieka a otaczajacym go środowiskiem zewnętrznym, równowagi umożliwiającej trwanie, rozwój i reprodukcję człowieka” (Karczewski 2002: 12).

Dla polityki zdrowotnej nowoczesnego państwa zdrowie społeczeństwa powinno być priorytetem, jako wartość umożliwiająca wszechstronny rozwój, dobrobyt i stanowiąca drogę do szczęścia osobistego i rodzinnego. Działalność profesjonalistów w dziedzinie zdrowia i higieny powinna skupiać się na edukacji w kierunku wykształcenia nawyków i zachowań niezbędnych do utrzymania potencjału zdrowotnego człowieka w każdym okresie życia. Przedstawiciele współczesnej koncepcji zdrowia środowiskowego uznają za priorytet równowage pomiędzy człowiekiem a środowiskiem, ponieważ w dobie cywilizacji technicznej nie zauważył on wyczerpywania się zasobów zdrowotnych i zagrożeń związanych ze skutkami swojej działalności. Nie docenia także zdrowia jako kapitału, umożliwiającego mu rozwój i odpowiedni poziom życia (Kulik 2002: 20).

Statystyki zdrowotne i raporty WHO wykazują wzrost zachorowalności i niepełnosprawności oraz przedwczesnych zgonów, których źródło tkwi w przemianach cywilizacyjnych. Efektem tego sa ustawy, dekrety i wytyczne dla poszczególnych regionów świata w zakresie realizacji zadań służących poprawie zdrowia społeczeństwa. Każde państwo w oparciu o statystyki zdrowotne i wyniki badań określa cele, opracowuje plany i sposoby ich realizacji oraz pozyskuje zasoby, środki i infrastrukture gwarantujące osiaganie planowanych rezultatów.

\section{Idea promocji zdrowia}

Promocja zdrowia została określona przez Międzynarodowa Konferencję Promocji Zdrowia w listopadzie 1986 r., w dokumencie Karta Ottawska Promocji Zdrowia, jako „proces umożliwiajacy każdemu człowiekowi zwiększenie oddziaływania na własne zdrowie w sensie jego poprawy i utrzymania" (Kulik 2002: 20). Oficjalna definicja zawarta w raporcie WHO z 1993 r. określa promocję zdrowia jako „działanie społeczne i polityczne na poziomie indywidualnym i zbiorowym, którego celem jest podniesienie stanu świadomości zdrowotnej społeczeństwa, krzewienie zdrowego stylu życia i tworzenie warunków sprzyjających zdrowiu. Jest to proces aktywizacji społeczności lokalnych, polityków, profesjonalistów i laików, podejmowanej dla osiagnięcia trwałych zmian zachowań (redukcji zachowań będących czynnikami ryzyka i rozpowszechniania zachowań prozdrowotnych) oraz wprowadzenia zmian w środowisku, które 
zmniejszałyby lub eliminowały społeczne i inne środowiskowe przyczyny zagrożeń zdrowia" (Karczewski, Grębowski 2002: 23).

Poczatkowo w dziedzinie promocji zdrowia skupiano się na jednostce, następnie podejmowano działania w kierunku poprawy warunków środowiskowych z uwzględnieniem wzmocnienia lokalnego kapitału społecznego, poprawy warunków środowiska pracy i włączenia do działań różnych instytucji (Karczewski, Grębowski 2002: 24). Strategicznym celem promocji zdrowia jest kształtowanie, wzmacnianie oraz optymalizacja statusu zdrowotnego jednostek i populacji. Celem edukacji prozdrowotnej jest szerzenie oświaty zdrowotnej, poprzez: wpływanie na zmiane zachowań prozdrowotnych człowieka, pobudzanie zainteresowania zdrowiem przez wzbogacanie wiedzy o nim, przekształcanie postaw i zachowań ludzkich w walce $\mathrm{z}$ nowymi zagrożeniami, wyrabianie odpowiedzialności za zdrowie własne i osób z najbliższego otoczenia. „Każdy powinien wiedzieć, co jest dla zdrowia szkodliwe, a co działa pozytywnie na organizm. Kiedy można z problemami zdrowotnymi radzić sobie samemu, a kiedy należy udać się do lekarza. Co wpływa na przedłużenie i harmonię życia, a co powoduje zakłócenia w równowadze fizycznej i psychicznej organizmu, przyczyniając się do skrócenia życia. Do zadań oświaty zdrowotnej należy także prowadzenie szeroko zakrojonych akcji majacych na celu walkę ze schorzeniami i nałogami zagrażajacymi ogółowi społeczeństwa. Edukacja prozdrowotna jest dyscyplina z pogranicza nauk medycznych, humanistycznych i społecznych. Pomocne w jej realizacji są także najnowsze osiagnnięcia z dziedziny psychologii i socjologii" (Gromadzka-Ostrowska 2003: 29).

Na poczatku lat 80 . XX w. Światowa Organizacja Zdrowia Biuro Regionalne dla Europy (WHO/EURO) przedstawiła nowa strategię działań na rzecz promocji zdrowia pod nazwa „Zdrowie dla Wszystkich”. W 1985 r. został opublikowany dokument zawierający 38 zadan dla poprawy zdrowia ludności, a następnie w wielu krajach opracowano narodowe programy zdrowia. W Polsce pierwsza wersje programu o nazwie Narodowy Program Zdrowia opracowano w 1990 r., zaś kolejne znowelizowane wersje opublikowano w latach 1993 i 1996. Żadna z tych wersji nie była w pełni realizowana z powodu braku wsparcia politycznego i społecznego, zainteresowania mass mediów, braku lobby. Niektóre resorty realizowały inne specyficzne programy, niezależnie od NPZ (Woynarowska 1999: 88-93).

Wraz z transformacja polityczna, ekonomiczna i społeczna pojawiły się nowe wyzwania i możliwości, ale także zagrożenia dla wielu populacji. Spowodowało to konieczność dalszej modyfikacji NPZ. W latach 2002 i 2006 powstały dokumenty strategiczne, których celem miał być harmonijny rozwój regionalny i skuteczna absorpcja środków wspólnotowych. 
W czerwcu 2005 r. ówczesna Rada Ministrów przyjęła przygotowana przez Ministerstwo Zdrowia Strategię Ochrony Zdrowia w Polsce na lata 2007-2013, która zawierała zapis, że przygotowany na lata 2007-2015 NPZ stanowi integralną część Strategii w zakresie zdrowia publicznego. Osiagnięcie celów NPZ jest możliwe pod warunkiem włączenia się do ich realizacji organów administracji rządowej, organizacji pozarządowych, samorządów i społeczności lokalnych oraz samych obywateli (Kuszewski, Goryński, Wojtyniak, Halik 2007: 11).

Uwzględniając cztery główne grupy czynników mających wpływ na zdrowie człowieka, styl życia - 50\%, środowisko fizyczne (naturalne, stworzone przez człowieka) i społeczne: życia, pracy, nauki - $20 \%$, czynniki genetyczne $-20 \%$ oraz działania służby zdrowia - $10 \%$, należy zdać sobie sprawę $\mathrm{z}$ tego, że ponad połowa $\mathrm{z}$ nich związana jest bezpośrednio z działalnością człowieka, który może reprezentować postawy chroniące lub niszczące potencjał zdrowotny. Dzięki zdobyczom cywilizacji człowiek uczynił życie wygodniejszym, ale też spowodował wiele szkód, poprzez niszczenie środowiska naturalnego, spadek aktywności fizycznej i produkcję wysoko przetworzonej żywności. Istotne znaczenie dla zdrowia mają warunki społeczno-ekonomiczne, zaś największym zagrożeniem jest ubóstwo i niski poziom wykształcenia (Kuszewski, Goryński, Wojtyniak, Halik 2007: 11). Promowanie zdrowego stylu życia i zwalczanie nieprawidłowych zachowań zdrowotnych powinno dotyczyć człowieka już od najmłodszych lat, tak aby uzyskana wiedza i umiejętności zostały utrwalone jako nawyki w dorosłym życiu. Obok rodziny, w której dziecko dorasta, ogromne znaczenie w kształtowaniu postaw dzieci i młodzieży maja placówki oświatowo-wychowawcze. Już na poziomie wychowania przedszkolnego realizowane sa programy edukacyjne o treściach związanych ze zdrowiem. Idea zdrowia siedliskowego realizowana jest pod hasłem „zdrowa szkoła”, „zdrowy dom”, „zdrowe miasto", itp. w formie projektów, do których przystępuja poszczególne instytucje i regiony kraju. W dalszej części opracowania przedstawione zostana formy realizacji celów NPZ przez placówki oświatowo-wychowawcze na przykładzie Sieci SzPZ.

\section{Szkoła Promujaca Zdrowie}

Realizacja programu Szkoła Promująca Zdrowie (SzPZ) opiera się na wychowaniu zdrowotnym i edukacji zdrowotnej dzieci i młodzieży przy zaangażowaniu wszystkich grup społecznych oraz instytucji związanych ze środowiskiem nauczania i wychowania. Według Demela wychowanie 
zdrowotne ,jest integralną częścią składowa kształtowania pełnej osobowości, a polega ono na: 1) wytwarzaniu nawyków bezpośrednio lub pośrednio związanych $\mathrm{z}$ ochrona i doskonaleniem zdrowia fizycznego i psychicznego; 2) wyrabianiu odpowiednich sprawności; 3) nastawieniu woli i kształtowaniu postaw umożliwiajacych stosowanie zasad higieny, skuteczna pielęgnacje, zapobieganie chorobom i leczenie; 4) pobudzaniu pozytywnego zainteresowania sprawami zdrowia przez epizodyczne i systematyczne wzbogacanie i pogłębianie wiedzy o sobie, a także o prawach rządzących zdrowiem publicznym" (Charońska 2008: 126).

Według T. Williamsa, edukacja zdrowotna jest procesem, w którym ludzie ucza się dbać o zdrowie własne i społeczności, w której żyja.. „Proces ten: koncentruje się na uświadamianiu związków między zdrowiem człowieka a jego stylem życia oraz środowiskiem fizycznym i społecznym; składa się z kilku etapów - od uświadamiania sobie problemów zdrowia do decyzji osobistych i/lub działań społecznych czy zachowań zdrowotnych" (Charońska 2008: 126).

Edukacja zdrowotna powinna przebiegać na trzech poziomach:

- podnoszenia poziomu wiedzy i umiejętności związanych z choroba, funkcjonowaniem własnego organizmu, zapobieganiem, radzeniem sobie w sytuacjach trudnych;

- podnoszenia poziomu wiedzy i umiejętności związanych z korzystaniem z systemu opieki zdrowotnej i pojmowaniem zasad jej funkcjonowania;

- zwiększania poziomu świadomości co do czynników społecznych, politycznych i środowiskowych wpływajacych na zdrowie (Charońska 2008: 127).

Wśród definicji edukacji zdrowotnej jedne kłada akcent na osobę edukowaną i zmiany dokonywane pod wpływem oddziaływań wychowawczych, inne za priorytet uznaja działania edukatorów zdrowia. Najkorzystniejszym rozwiązaniem sa takie, które łączą oba procesy w całość, np. według Woynarowskiej „[edukacja zdrowotna] jest to proces przekazywania i/lub nabywania wiedzy oraz umiejętności niezbędnych do przeżycia i poprawy jakości życia” (Charońska 2008: 128).

Edukacja zdrowotna obejmuje cały cykl życia człowieka. Systematyczne i zamierzone działania wychowawcze rodziców, nauczycieli i wychowawców pomagają dziecku w przyswojeniu nawyków zdrowotnych. W dalszym okresie wzrastania i rozwoju człowiek dokonuje wyborów $\mathrm{w}$ sprawach zdrowia pod wpływem różnych czynników środowiska fizycznego, społecznego i kulturowego. Edukacja zdrowotna nie ma na celu „zniewolenia” człowieka poprzez wywieranie presji, tylko budowanie zdolności do działania, czyli kompetencji (wiedzy, umiejętności, 
sprawności oraz postaw i wartości niezbędnych do realizacji zadań). Kompetencje zdobywane sa poprzez doświadczenia życiowe (wiedzę potoczna, obyczaje, modę) oraz proces nauczania i wychowania. Kluczowymi kompetencjami na rzecz zdrowia są: umiejętności dbania o zdrowie, motywacje do zachowania prozdrowotnego i wiedza na temat realizacji zasad zdrowego stylu życia (Charońska 2008: 129-131).

Ruch szkół promujacych zdrowie pn. „Zdrowa szkoła” został zainicjowany i opublikowany na przełomie lat 80. i 90. ubiegłego stulecia. W 1992 r. utworzono Europejską Sieć Szkół Promujących Zdrowie, która obecnie funkcjonuje w 45 krajach. Patronat nad nia obejmuje Rada Europy, Komisja Europejska i Światowa Organizacja Zdrowia. Celem rozwoju tego ruchu jest poprawa jakości życia ludzi w zjednoczonej Europie, dzięki przygotowaniu młodego pokolenia do zdrowego stylu życia, aktywnego uczestnictwa w budowaniu demokracji, tolerancji, poszanowania praw człowieka, otwarcia na inne kultury oraz kształtowania poczucia odpowiedzialności za siebie i innych.

Polska przystapiła do Europejskiej Sieci SzPZ w 1992 r., dzięki prekursorce, prof. Barbarze Woynarowskiej, która zapoczątkowała działania w Instytucie Matki i Dziecka, i była pierwszym koordynatorem polskiej sieci. Na mocy porozumienia zawartego w dniu 1 września 2000 r. pomiędzy ministrem edukacji narodowej i ministrem zdrowia w sprawie wspierania edukacji zdrowotnej w szkole oraz rozwoju Sieci Szkół Promujacych Zdrowie, powierzono obowiązki Krajowego Koordynatora Programu Marii Sokołowskiej z Centrum Metodycznego Pomocy Psychologiczno-Pedagogicznej, zaś funkcję Zastępcy Krajowego Koordynatora Programu doc. Aldonie Sito z Instytutu Matki i Dziecka. Według danych z 2008 r. do sieci przystapiło ponad 1200 polskich szkół. SzPZ ma swoje logo i deklaracje przyjęta podczas I Europejskiej Konferencji Szkół Promujących Zdrowie, o treści: „Każde dziecko ma prawo i powinno mieć możliwość uczyć się w szkole promującej zdrowie" (Sokołowska 2008: 204-205). Jak podaje Sokołowska, według WHO: „Szkoła promująca zdrowie zwiększa możliwości młodych ludzi do podejmowania działań i dokonywania zmian. Jest miejscem, w którym młodzi ludzie, pracując razem $\mathrm{z}$ nauczycielami i innymi osobami, mogą osiągnać sukces. Wzmacnianie młodych ludzi, wspieranie ich wizji i idei umożliwia im wpływ na ich życie i warunki życia” (Sokołowska 2008: 206).

Program SzPZ składa się z pięciu etapów:

1. Okresu przygotowawczego (popularyzowanie idei w społeczności szkolnej i lokalnej, pozyskiwanie uczestników, sojuszników, powołanie szkolnego koordynatora i zespołu promocji zdrowia, podjęcie wzajemnych zobowiązań przez osoby zainteresowane współtworzeniem szkoły promującej zdrowie). 
2. Diagnozy stanu wyjściowego (zebranie i przeanalizowanie danych dotyczących aktualnych problemów ludzi i warunków funkcjonowania szkoły oraz ustalenie listy problemów wymagajacych rozwiązania).

3. Budowania planu działań (określenie celu polegającego na rozwiązaniu tzw. problemu priorytetowego, wynikłego z diagnozy oraz zbudowanie planu działań pozwalających na usunięcie przyczyn problemu).

4. Działania (realizacja planu, monitorowanie działań oraz dokonywanie niezbędnych korekt).

5. Ewaluacji wyników działań (Sokołowska 2008: 207).

W 2002 r. odbyła się II Europejska Konferencja Szkół Promujących Zdrowie w Holandii, pod hasłem „Partnerstwo sektorów zdrowia i edukacji”, co uznano za jeden z priorytetów w sieci europejskiej i krajowej, ponieważ poprawa stanu zdrowia społeczeństwa wymaga współdziałania i zaangażowania interdyscyplinarnego. Koordynatorzy programu i dyrektorzy placówek oświatowo-wychowawczych przystępujących do sieci, spotykaja się na konferencjach tematycznych, wymieniaja doświadczenia i korzystają ze szkoleń obejmujących problematykę zdrowia, profilaktyki, chorób, niepełnosprawności. Realizatorzy programu otrzymuja poradniki i przewodniki umożliwiajace opracowanie metod i form nauczania dzieci i młodzieży dostosowanych do potrzeb i poziomu wiedzy uczniów ${ }^{1}$.

Poszczególne etapy edukacji prozdrowotnej obejmują:

- wychowanie przedszkolne (wprowadzenie dziecka w zagadnienia zdrowia w oparciu o zachowania i nawyki zdrowotnego stylu życia wyniesione z rodziny);

- kształcenie zintegrowane w klasach I-III szkoły podstawowej (kształtowanie właściwych nawyków higienicznych, umiejętności nawiązywania i utrzymywania poprawnych kontaktów interpersonalnych z rówieśnikami i dorosłymi, w tym z osobami niepełnosprawnymi: poznawanie własnego ciała, dbałość o zdrowie oraz higienę własną i otoczenia, żywność i żywienie, bezpieczeństwo, umiejętność słuchania, podobieństwa i różnice między ludźmi, tolerancja, organizacja własnego warsztatu pracy);

- nauczanie blokowe w klasach IV-VI szkoły podstawowej (rozbudzenie zainteresowań ucznia własnym zdrowiem i rozwojem: nabywanie umiejętności dbania o swoje zdrowie, wskazanie zagrożeń cywilizacyjnych i społecznych, kształtowanie umiejętności właściwego zachowania się podczas: kontaktu z przedmiotami

\footnotetext{
${ }^{1}$ Wiele publikacji jest autorstwa Barbary Woynarowskiej i Marii Sokołowskiej.
} 
niebezpiecznymi i toksycznymi, konfliktu w relacjach społecznych, organizacja czasu wolnego i nauki w domu, rozpoznawanie i umiejettne reagowanie na zagrożenie);

- nauczanie przedmiotowe $\mathrm{w}$ gimnazjum (przygotowanie ucznia do samodzielności w zakresie zdrowego stylu życia i dokonywania właściwych wyborów: wskazanie źródeł pomocy w przypadku zagrożenia uzależnieniami, prostytucją, molestowaniem seksualnym, higiena osobista i otoczenia, bezpieczeństwo i pierwsza pomoc, zasady odżywiania, aktywność ruchowa i umysłowa, korzystanie z pomocy medycznej, poczucie własnej wartości, dawanie i przyjmowanie wsparcia, asertywność, przyczyny i skutki używania środków psychoaktywnych, sposoby radzenia sobie w sytuacjach trudnych);

- ścieżka edukacyjna w szkołach ponadgimnazjalnych (kształtowanie samodzielności ucznia i utrwalanie zachowań zdrowotnych ważnych w codziennym życiu z uwzględnieniem przyszłości: utrwalanie umiejętności życiowych sprzyjających rozwojowi fizycznemu, psychicznemu, społecznemu i duchowemu, kształtowanie aktywnej i odpowiedzialnej postawy wobec zdrowia i bezpieczeństwa własnego oraz innych ludzi, rozbudzenie potrzeby działania na rzecz tworzenia zdrowego środowiska, wzmacnianie poczucia własnej wartości, rozwijanie współpracy z rodzicami i społecznościa lokalna, pielęgnacja ciała i urody, znaczenie pracy i aktywnych form spędzania czasu wolnego, związek poczucia humoru ze zdrowiem, racjonalne żywienie i skutki odchudzania, pomoc medyczna i psychologiczna, zachowanie w chorobie, radzenie sobie w sytuacjach trudnych i umiejętność wspierania innych, porozumiewania się i utrzymywania dobrych relacji z ludźmi oraz funkcjonowania i współpracy $\mathrm{w}$ grupie, radzenie sobie $\mathrm{z}$ presja środowiska, kształtowanie właściwej postawy wobec osób chorych, niepełnosprawnych i starszych). Metody i treści edukacji zdrowotnej powinny być odpowiednio dobrane i dostosowane do poziomu wiedzy, rozwoju i specyfiki grupy (Wolny 2009: 43-51).

\section{Rozwój Sieci Szkół Promujących Zdrowie w województwie podkarpackim}

Wojewódzka Sieć Szkół Promujących Zdrowie (WSSzPZ) powstała w 1999 r. Powołano również Wojewódzki Zespół Wspierajacy Szkoły Promujace Zdrowie (WZWSzPZ), na mocy porozumienia: Kuratorium 
Oświaty w Rzeszowie, Urzędu Marszałkowskiego w Rzeszowie, Komendy Wojewódzkiej Policji w Rzeszowie, Wojewódzkiej Stacji Sanitarno-Epidemiologicznej w Rzeszowie, Wojewódzkiego Ośrodka Matki, Dziecka i Młodzieży w Rzeszowie, Zarządu Miasta Rzeszowa, ośrodków doskonalenia nauczycieli w Czudcu i Przemyślu. Funkcję Wojewódzkiego Koordynatora zespołu powierzono Jadwidze Kaźmierczyk. We wrześniu 1999 r. Zespół podjął decyzję o przyjęciu do sieci pierwszych 22 szkół i placówek. W dniu 4 listopada 1999 r. w Urzędzie Wojewódzkim w Rzeszowie odbyło się uroczyste spotkanie zorganizowane przez Kuratorium Oświaty w Rzeszowie i WZWSzPZ, w której wzięła udział prof. Barbara Woynarowska - Przewodniczaca Krajowego Zespołu ds. Promocji Zdrowia i Edukacji (Dominik 2001: 5-6).

Dzięki dużemu zainteresowaniu ze strony przedstawicieli resortu edukacji, w 2001 r. do sieci przystapiło 6 kolejnych placówek, a 36 oczekiwało na przyjęcie. W 2005 r. WSSzPZ liczyła już 230 placówek, w 2007 r. - 314, zaś obecnie obejmuje ponad 400 placówek. Dzięki zaangażowaniu wszystkich przedstawicieli społeczności lokalnej zauważono wymierne korzyści, w postaci podnoszenia poziomu wiedzy na temat zdrowego stylu życia i umiejętności rozpoznawania sytuacji zagrażajacych bezpieczeństwu oraz zdrowiu członków rodziny. Współpraca różnych przedstawicieli środowiska lokalnego pomogła w nawiązywaniu więzi międzypokoleniowej i dobrych relacji interpersonalnych oraz pobudzała wrażliwość na drugiego człowieka i chęć świadczenia pomocy w potrzebie. Realizowane projekty dotyczyły różnych aspektów zdrowia jednostki i populacji. Dzięki życzliwości obecnego Wojewódzkiego Koordynatora WZWSzPZ, pani Marioli Kiełboń, która udostępniła autorce teksty sprawozdań z działalności sieci w województwie, możliwe było przedstawienie problematyki w tej części opracowania.

\section{Monitorowanie pracy szkół i placówek w zakresie edukacji zdrowotnej i promocji zdrowia ${ }^{2}$}

W 2005 r. Kuratorium Oświaty w Rzeszowie przeprowadziło badanie ankietowe Szkół Promujących Zdrowie. Wypełniony „Arkusz Monitorowania Pracy Szkoły Promującej Zdrowie” przesłało 267 szkół i placówek. Dyrektorzy udzielili odpowiedzi na 19 pytań na temat pracy szkoły w zakresie edukacji prozdrowotnej i promocji zdrowego stylu życia, popularyzacji sportu i rekreacji. Analiza wyników wykazała,

\footnotetext{
${ }^{2}$ Przedruk z materiałów pozyskanych za zgodą Wojewódzkiego Koordynatora Zespołu mgr Marioli Kiełboń.
} 
że SzPZ realizują wiele programów i projektów edukacyjnych z zakresu edukacji prozdrowotnej, także w ramach grantów ministerialnych. Najważniejsze z nich to: „Janko Muzykant” - wyrównywanie szans edukacyjnych dzieci i młodzieży ze środowisk wiejskich; „Drugi elementarz - program siedmiu kroków” - profilaktyka uzależnień; „Różowa wstążeczka”; „Socrates Comenius 3.2 POSSE - profilaktyka antynowotworowa, edukacja żywieniowa; „Kształtowanie umiejętności życiowych uczniów w praktyce szkolnej”; „Tworzenie warunków aktywnego udziału dzieci i młodzieży w programach promocji zdrowia i profilaktyki z wykorzystaniem edukacji rówieśniczej”; „Spójrz inaczej”; „Domowi Detektywi” - profilaktyka uzależnień; „Sport przeciw uzależnieniom” - program profilaktyki przeciwalkoholowej; „Proste plecy”; „Do zdrowia przez sport".

100\% przedszkoli, szkół i placówek realizuje wiele autorskich programów edukacyjnych, wychowawczych i profilaktycznych opracowanych zgodnie z potrzebami i oczekiwaniami środowiska szkolnego, m. in. z zakresu promocji zdrowego stylu życia, popularyzacji sportu i rekreacji: „Dzień sportu szkolnego”; „Zdrowy człowiek to człowiek szczęśliwy”; „Aktywnym być - zdrowym być”; „Aerobik dla rodziców i uczniów”; „Zdrowy styl życia umacnia nasze zdrowie” $i$ inne.

We wszystkich szkołach w skład zespołu koordynujacego działania z zakresu promocji zdrowia wchodzą: nauczyciele wychowania fizycznego, biologii, chemii, fizyki, matematyki, przedmiotów zawodowych, bibliotekarz, pedagog szkolny, pielegniarka, rodzice, intendent, „zaprzyjaźniony” lekarz. Przedszkolaki oraz uczniowie pod kierunkiem nauczycieli i rodziców biora udział $\mathrm{w}$ zajęciach pozalekcyjnych, organizowanych przez szkołe $\mathrm{i}$ inne instytucje w ciagu roku szkolnego i w okresie ferii zimowych. Najczęściej wymieniano zajęcia ruchowe na basenie, zajęcia sportowe, olimpiady sportowe, kuligi, szkolenia na kartę rowerowa, rajdy rowerowe, konkursy sprawnościowe, pikniki rodzinne, zielone szkoły, gimnastykę korekcyjną, organizację zabaw podczas przerw międzylekcyjnych.

Przeprowadzona ewaluacja wykazała, że należy: utrzymać na wysokim poziomie ofertę zajęć pozalekcyjnych, zorganizować dodatkowo koła zainteresowań - SKS, w większym stopniu organizować rodzinne wyjazdy turystyczne, imprezy sportowe i rekreacyjne, zachodzi konieczność organizacji czasu wolnego uczniów, uwzględniając ich zainteresowania, należy stosować $\mathrm{w}$ pracy sprzęt sportowy, jaki dzieci posiadaja $\mathrm{w}$ domu, w szerszym zakresie uwzględnić elementy turystyki kwalifikowanej, w większym stopniu zadbać o otoczenie szkolne - boiska, place zabaw, zgromadzić fundusze na doposażenie ogrodu przedszkolnego w sprzęt sportowo-rekreacyjny, ścieżkę zdrowia, poszerzyć zakres 
obchodów szkolnego dnia zdrowia, w większym stopniu zaangażować rodziców w organizację imprez szkolnych i środowiskowych ${ }^{3}$. Aktualna problematyka realizowana przez SzPZ dotyczy bezpieczeństwa dzieci i młodzieży w zakresie ochrony przed krzywdzeniem i przemocą.

Metody pracy w Szkole Promującej Zdrowie, stosowane w edukacji prozdrowotnej, wymagaja od nauczyciela uzupełniania wiedzy medycznej i łączą edukację z procesem wychowania. Nauczyciele otrzymuja opracowane scenariusze zajęć aktywizujące uczniów, którzy ujawniaja swoje problemy zdrowotne i rodzinne. Pomaga to nauczycielowi poznać ucznia oraz podejmować działania profilaktyczne i prewencyjne w przypadku zagrożeń.

Przygotowanie do pracy metodami aktywizującymi wymaga od nauczyciela: umiejętności określenia granic swoich kompetencji; poznania zasad prowadzenia wstępnej rozmowy z uczniem mającym poważne problemy; umiejętności współpracy z rodziną dziecka; nieobarczania się odpowiedzialnościa za całkowite i natychmiastowe rozwiąanie problemów ucznia; wiedzy na temat możliwości i miejsc poszukiwania pomocy oraz wsparcia przez wszystkie osoby majace zajać się problemem (nauczyciel, uczeń, rodzina we współpracy z pedagogiem szkolnym, poradnią psychologiczno-pedagogiczna, lekarzem, ośrodkiem pomocy społecznej itp.) (Woynarowska, Sokołowska 2001: 33-34).

\section{Podsumowanie}

Tempo i charakter przemian społecznych, politycznych, gospodarczych i kulturowych nie pozwala człowiekowi na izolowanie sie od spraw publicznych, ze względu na wzajemne oddziaływanie na siebie różnych osób i grup zawodowych, towarzyskich i nieformalnych podczas pełnienia ról społecznych. Niepewna sytuacja ekonomiczna, kryzys, bezrobocie, migracje, zanik więzi międzypokoleniowych naraża człowieka na stres i osamotnienie. Nierozsadne gospodarowanie zasobami przyrody i degradacja środowiska naturalnego oraz błędy popełniane w zachowaniach i aktywności związanej ze stylem życia odbija się niekorzystnie na naszym zdrowiu. Rodzina współczesna nie zawsze jest dobrym wzorcem dla młodego pokolenia do kształtowania postaw wobec zdrowia, z powodu złych nawyków lub braku czasu, co przekłada się na statystyki chorób cywilizacyjnych, np. alergii, otyłości i cukrzycy u dzieci i młodzieży. Idea szkół promujących zdrowie jest dobrą alternatywą dla rozwiązywania

\footnotetext{
${ }^{3}$ M. Kiełboń, Monitorowanie pracy szkót i placówek $w$ zakresie edukacji zdrowotnej i promocji zdrowia, mps.
} 
problemów zdrowotnych nie poprzez naprawę dzięki wynalazkom medycyny, które sa kosztowne, ale przez dobrowolne stosowanie zasad racjonalnego stylu życia, zanim pojawi się problem zdrowotny lub zanim młody człowiek utrwali sobie niewłaściwe nawyki zdrowotne.

\section{Bibliografia}

Charońska E. (2008), Podstawy teoretyczne edukacji zdrowotnej, [w:] A. Andruszkiewicz, M. Banaszkiewicz. (red.), Promocja zdrowia. Teoretyczne podstawy promocji zdrowia, Wydawnictwo Czelej, Lublin.

Dominik D. (2001), Szkoła promujaca zdrowie, Podkarpacki Ośrodek Doskonalenia Nauczycieli, Rzeszów.

Gromadzka-Ostrowska J. (2003), Zagadnienia zdrowia publicznego i ochrony środowiska, [w:] J. Gromadzka-Ostrowska, D. Włodarek, Z. Toeplitz, Edukacja prozdrowotna, Wydawnictwo SGGW, Warszawa.

Karczewski J. K., Grębowski R. (2002), Czynniki decydujace o zdrowiu człowieka, [w:] J. K. Karczewski (red.), Higiena, Wydawnictwo Czelej, Lublin.

Karczewski J. K. (2002), Pojęcie zdrowia, [w:] J. K. Karczewski (red.), Higiena, Wydawnictwo Czelej, Lublin.

Kulik T. B. (2002), Koncepcja zdrowia w medycynie, [w:] T. B. Kulik, M. Latalski (red.), Zdrowie publiczne, Wydawnictwo Czelej, Lublin.

Kuszewski K., Goryński P., Wojtyniak B., Halik R. (2007), Narodowy Program Zdrowia na lata 2007-2015, Ministerstwo Zdrowia, Warszawa.

Sokołowska M. (2008), Szkoła promujaca zdrowie, [w:] A. Andruszkiewicz, M. Banaszkiewicz (red.), Promocja zdrowia. Teoretyczne podstawy promocji zdrowia, Wydawnictwo Czelej, Lublin.

Wolny B. (2009), Edukacja zdrowotna w szkole, Stalowa Wola.

Woynarowska B. (1999), Narodowy Program Zdrowia - ewolucja, możliwości realizacji, [w:] J. B. Karski (red.), Promocja zdrowia, Warszawa.

Woynarowska B., Sokołowska M. (2001), Ścieżka edukacyjna, edukacja - prozdrowotna $i$ promocja $z$ drowia $w$ szkole, Warszawa.

\section{Shaping children's and teenagers' attitudes towards health as a value. Development of the Network of Health Promoting Schools in the Podkarpackie Region}

The study discusses the historical and contemporary approach to individual's and society's health in terms of the lifestyle and man's relation to the environment. In accordance with the settings approach to health it is necessary to identify factors which prevent health losses and protect health potential. The state's health policy aims at eliminating hazards and enhancing knowledge and skills of individuals, their families and the entire society with regard to health in its physical, mental and social dimensions. The World Health Organization (WHO) elaborates reports on health issues worldwide which determine objectives introduced to health programs. One of the 
measures aimed at promoting health is the Network of Health Promoting School (HPS). The implementation of the Health Promoting School (HPS) program aims at providing health-oriented upbringing and education to children and teenagers, where all social groups and institutions connected with teaching and educational environment are involved. The article presents the program's objectives and implementation in the Podkarpackie Region, and is based on materials provided by the Regional Coordinator of the HPS Program. School.

Key words: health, health promotion, National Health Program, Health Promoting 